\title{
Kabin Ekibinin Mesleki Tükenmişlik Düzeyinin İncelenmesi: Bir Özel Havayolu Şirketi Örneği
}

\author{
Serdar KIZILCAN1 \\ 1 Ögrr.Gör., Ussak Üniversitesi, serdar.kizilcan@,usak.edu.tr \\ Gülten DEMİRAL 2 \\ ${ }^{2}$ Dr. Ögrr. Üyesi, Usak. Universitesi, gulten.demiral@usak.edu.tr
}

Geliş Tarihi/Received: 21.06.2021～Kabul Tarihi/Accepted: 11.08.2021： „-Yayım/e-Printed 31.08.2021

ORCID: 0000-0002-8209-2804, 0000-0001-5132-808X

\section{ÖZET}

Tükenmişlik, hayata ve çalışma ortamına karşı olumsuz tutumların geliştiği, kişisel anlamda yetersizlik duygusunun oluştuğu, zihinsel ve fiziksel açıdan yıpranmışlık, geleceğe dair umutsuzluk, çaresizlik gibi belirtilerin görüldüğ̈̈ bir durum olarak ifade edilebilir. Tükenmişlik, her meslek grubunda ortaya çıkabilecek psikolojik bir rahatsızlık olmakla birlikte özellikle hizmet sektöründe çalışan bireylerde daha sık görülebilmektedir. Havayolu şirketlerinin vitrini durumunda olan kabin ekiplerinin yüz-yüze hizmet vermeleri, emek yoğun çalışmaları, düzenli mesai kavramlarının olmayışı gibi etkenler bir takım sıkıntıları beraberinde getirmektedir. Tükenmişlik sendromunu yaşayan kabin ekibi çalışanlarının uçuşlarına katılmamaları, çalışırken işe odaklanamamaları, yolcuya verilen hizmetin düşük olması şirketler için de maliyet ve imaj kaybına neden olmaktadır. Bu çalışmada; kabin ekiplerinin tükenmişlik düzeylerinin ölçülmesi ve elde edilen sonuçların demografik faktörlere göre değerlendirilmesi amaçlanmıştır. Verileri elde etmek amacıyla Maslach Tükenmişlik Envanteri kullanılmış ve Antalya'da faaliyet gösteren bir özel havayolu şirketinin kabin ekibi çalışanlarına anket çalışması uygulanmıştır. Çalışmanın sonuçlarına göre; gençlerin tükenmişlik düzeylerinin daha fazla olduğu, yaş ilerledikçe çalışanların duygusal tükenme, duyarsızlaşma ve düşük kişisel başarı düzeylerinin azaldığ1 görülmektedir. Evli olan ve de çocuk sahibi olan işgörenlerin beklenenin aksine tükenmişlik alt boyutları anlamında etkilenmedikleri görülmektedir. Çalışma statüsü ile tükenmişlik alt boyutları arasında anlamlı bir ilişki olduğu saptanmıştır.

Anahtar Kelimeler: Tükenmişlik, Sivil Havacılık, Sivil Havacılık Kabin Hizmetleri, Havayolu Şirketi, Kabin Ekibi 


\title{
The Inspection of Occupational Burnout Level of Flight Cabin Crew: Sample Study For A Private Airline
}

\begin{abstract}
Burnout can be expressed as a situation in which negative attitudes towards life and work environment develop, a sense of personal inadequacy occurs, symptoms such as mental and physical weariness, hopelessness about the future, and helplessness are seen. Burnout is a psychological disorder that may occur in every profession group, but it can be seen more frequently in individuals working in the service sector. Factors such as face to face service of the cabin crews who are showcase of the airline companies, their labor intensive work and the absence of regular working hours, bring along some problems. Cabin crew members who experience burnout syndrome, not attending their flights, not being able to focus on work while working, and low service to the passenger cause cost and image loss for companies. In this study, the intended is o measure the burnout of cabin crews and to evaluate the results according to the demographic factors. Maslach Burnout Inventory was utilized to collect data and a survey study was applied to cabin crew employees working in a private airline company operating in Antalya. According to the results of the study; young people become more exhausted, when working people become older, employees have lower levels of emotional exhaustion, depersonalization and low personal accomplishment. Contrast to general thoughts married working people and working people who have children are not more influenced sub- dimensions of burnout. A significant relationship was found between work status and the sub-dimensions of burnout.
\end{abstract}

Keywords: Burnout, Civil Aviation, Civil Aviation Cabin Services, Airline Company, Cabin Crew

*Bu çalışma, birinci yazarın yüksek lisans tezinden üretilmiştir.

\section{GİRİ̧̧}

Sivil havacılık faaliyetleri, günümüzde küresel ilişkiler ağının ve uluslararası ticaretin en önemli katalizörlerinden biri haline gelmiştir. Ülkemizde, 2003 y1lında uygulanan 'serbest havacılık" politikasıyla birlikte havayolu şirketlerinin sayısı artmış, havacılık sektörü ciddi bir ivme kazanmıştır. 2020 yıl sonu itibarıyla Türkiye'de sivil havacılık sektöründe toplam 10 adet havayolu şirketi faaliyet göstermektedir (Shgm, 2020: 28). Artan altyap1 ve filo yatırımları, uçak sayılarına da yansımıştır. 2003 y1lında Türkiye'de faaliyette bulunan havayolu şirketlerindeki toplam uçak sayısı 162 iken, bu say1 2020 yıl sonu itibarıyla 554'e ulaşmıstır (Shgm, 2020: 30).

Geçmişten günümüze sivil havacılık sektörünün sürdürülebilir büyümesindeki unsurlardan biri de nitelikli personel ihtiyacının karşılanmasıdır. Aynı zamanda sektörel 
büyüme sonucunda artan rekabet koşulları, hem iç hatlarda hem de dış hatlarda faaliyet gösteren havayolu şirketlerini daha kaliteli hizmet sunmaya ve müşterilerinin beklentilerini karşılamaya zorlamaktadır. Kaliteli hizmet sunmanın ve beklentileri karşılamanın ana koşullarından biri de işini seven, benimseyen ve yüksek verimlilikle çalışan personelin varlı̆̆ıdır.

Tükenmişlik yaşayan bireylerin zihinsel ve bedensel olarak bir takım ciddi rahatsılılılar yaşadığını öngördüğümüzde, bu kişilerin hizmet verdikleri insanlara karşı olumsuz davranışlar sergileyeceği ve standartların altında hizmet vereceği düşünülebilir. Böylece, tükenmişlik yaşayan bireyin kendisine, hizmet verdiği kişilere ve örgüte zarar vereceğini söylemek yanlış olmayacaktır (Helvacı ve Turhan, 2013: 59). Çalışmada, kabin ekibi çalışanlarının tükenmişlik düzeylerinin ölçülerek elde edilen sonuçların demografik faktörlere göre değerlendirilmesi amaçlanmış ve önerilerde bulunulmuştur. Bu bağlamda tükenmişlik kavramı ve alt boyutları, tükenmişliğe etki eden faktörler, tükenmişliği önlemek için kullanılan yöntemler, kabin ekibinin görev ve sorumlulukları ile çalışma koşulları kavramsal olarak ele alındıktan sonra araştırma bulgularına, sonuç ve önerilere yer verilmiştir.

\section{KAVRAMSAL ÇERÇEVE}

\subsection{Tükenmişlik Kavramı ve Alt Boyutları}

Günümüzün dünyasında hayat koşulları, çalsşma şartları ve toplum yapısı sürekli bir değişim ve gelişim halindedir. Teknolojide yaşanan yenilikler, yaşam standartlarının yükselmesi, bireylerin toplumun her alanında var olmasını ve değişime ayak uydurmasını zorunlu bırakmaktadır. Bu süreçlerin hepsinde varlık göstermek isteyen bireyler adapte olmakta zorlanmakta, kendilerini yoğun stres altında zayıf ve korunmasız hissetmektedirler. Sonuç olarak, sosyal ilişkilerinde kimi zaman başarısız olacaklar ve iş hayatında uyum sorunu yaşayıp kendilerini tatminsiz hissedeceklerdir. Kişisel, sosyal ve mesleki anlamda yetersiz hisseden birey aslında çağımızın önemli sorunlarından biri olan tükenmişlik sendromuyla karşı karşıyadır (Sürgevil, 2006).

Tükenmişlik kavramı, ilk kez ayrıntılı olarak psikolog Herbert Freudenberger (1974) tarafindan ortaya koyulmuştur. Bu kavram başarısızlıktan, yıpranmadan, enerji ve güç kaybından ötürü ya da kişinin iç kaynaklarında karşılanamayan istekleri yüzünden oluşan bir tükenme halidir. Sonraki yllarda ise Maslach ve Jackson (1981), tükenmişlik kavramının tanımını kişide meydana gelen uzun süreli fiziksel yorgunluk, umutsuzluk ve çaresizlik 
duyguları ile beraber kişinin yapmış olduğu işe, diğer insanlara ve hayata karşı göstermiş olduğu olumsuz tutumları içeren, zihinsel ve fiziksel boyutu olan bir sendrom olarak yapmıslardır (Pepe, 2008: 2).

Tükenmişlik ile ilgili yaptığı çalışmada Jones, tükenmişliğin kişilere yönelik psikolojik stresten kaynaklandığını belirtse de aslında; hizmet veren kişiler ile hizmet alan müşteriler arasındaki ilişkinden kaynaklanan stresin tükenmişliği daha çok etkilediğini vurgulamıştır. Aynı zamanda tükenmişlik kavramının bireysel ve fiziksel yorgunluğun ötesinde mesleki süreçteki değişimi içeren bir kavram olarak düşünülmesi gerektiğini dile getirmiştir (Jones'den akt. Barutçu ve Serinkan, 2008: 545).

Cherniss (1980) tükenmişlik kavramını, yoğun stres ve doyumsuzluk yaşayan kişinin psikolojik anlamda yaptığı işten soğuması olarak özetlemiştir. Kavla (1998), tükenmişliğin negatif bir deneyim olduğunu, bireyin ve çevresi arasındaki karşlıklı etkileşim ile sonuçlandığını belirtmiştir (Yılmaz ve Karahan, 2009: 203).

Tükenmişlik birden bire ortaya çıkmayan, yavaş ve sinsice gelişen bir sendromdur. Tükenmişliğin belirtileri göz ardı edilirse tükenmişlik ilerler ve başa çıkılmaz bir sorun haline gelir. Bu yüzden tükenmişliğin gizlice gelişen belirtileri iyi bilinmeli ve bu belirtiler zamanında teşhis edilip gereken tedbirlerin alınması gerekir (Ardıç ve Polatcı, 2008: 73).

Maslach ve Jackson (1986), tükenmişlik kavramını üç alt boyutta ele almışlardır. Bu boyutlar duygusal tükenme, duyarsızlaşma ve düşük kişisel başarı şeklinde ifade edilmektedir.

\subsubsection{Duygusal tükenme}

Duygusal açıdan yoğun iş temposu içinde olan kişiler, kendilerini zorlarlar. Başkalarının duygusal talepleri onları sindirir. Duygusal tükenme, bu gibi durumlara karşı bir reaksiyon vermek amacıyla ortaya çıkmış olup, çalışanların duygularındaki artış olarak tanımlanmaktadır. Örneğin; kişinin kendini bitkin ve duygusal açıdan aşırı yorgun hissetmesi gibi (Maslach ve Jackson, 1986: 99).

Birey, kendini bitip tükenmiş hisseder. Artık kendine gelme şansı yokmuş gibi düşünür. Duygusal tükenme yaşayan insanlar, sabah uyandıkları zaman kendilerini dinlenmemiş ve hala yorgun hissederler. Başkalarıyla muhatap olmak ve yeni projelerde yer almak için gerekli olan enerjinin kendilerinde kalmadığını düşünürler (Maslach ve Leiter'den akt. Karacaoğlu ve Çetin, 2015: 51). 


\subsubsection{Duyarsızlaşma}

Duyarsızlaşma, kişinin çalışma hayatında iş arkadaşlarının ve hizmet verdiği insanların duygularının olmadığını varsayarak kişisel ve insani özelliklerini göz ardı ederek davranışs sergilemesidir (Arpacı ve Özek, 2019: 105).

Duygusal tükenmeyi yaşayan kişi, başkalarının sorunlarını çözme konusunda kendini güçsüz hisseder ve yetersiz olduğunu düşünür. Kaçış yolu denemek, yaşamış olduğu duygusal yükü hafifletmek için bir yöntemdir. Etrafiyla olan ilişkisini en az seviyeye düşürür. Bunlar, bu boyutun ilk belirtileri olarak karşımıza çıkar. Birey, başkalarıyla anlamlı ilişkiler kurmak istemez (Işıkhan, 2004).

\subsubsection{Düşük Kişisel Başarı}

Kişi başkaları hakkında olumsuz şeyler düşündüğünde, zamanla bu düşünceler kendisi hakkındaki düşünceleri de olumsuz yönde etkiler. Dolayısıyla bu olumsuz düşünceler ve yanlş davranışlar, kişinin kendisini suçlu hissetmesine sebep olur. Diğer insanlar tarafından sevilmediğine dair düşünce geliştirir. Kendisini başarısız olduğuna inandırır. $\mathrm{Bu}$ aşamadan sonra düşük kişisel başarı hissi meydana gelir (Örmen, 1993:3).

Böylece kişinin kendine olan saygısı ortadan kalkabilir. Harcadığı çabanın boşuna olduğunu ve başarılarının değerlendirilmediğini düşündügünde var olan stresin giderek artması ve depresyon belirtilerinin ortaya çıkması kaçınılmazdır. Kişi, yaptıklarının değişiklik yaratmayacağına inandığında ise artık uğraşmaz (Gezer, Yenel ve Şahin, 2009).

\subsection{Tükenmişliğe Etki Eden Bireysel ve Örgütsel Faktörler}

Çalışanın mesleği, çalıştığı kurum ve kişisel yeterlilikleri, çalışanın beklentilerini karşılamıyorsa ya da kişinin beklentileri gerçekçi değilse tükenmişliğin artması kaçınılmazdır. Yapılan araştırmalar, tecrübesiz ve genç çalışanların tecrübeli ve yaşlı çalışanlara göre daha çok tükendiğini göstermektedir. $\mathrm{Bu}$ da insanların farklı beklenti düzeylerinden kaynaklanmaktadır (Izgar, 2003).

Bireyin cinsiyeti, eğitim düzeyi, yaşı ve medeni durumu da tükenmişlik ihtimalini artırabilmekte veya azaltabilmektedir. Cinsiyet faktörü göz önüne alındığında kadınlarda duygusal tükenmenin erkeklere göre çok daha fazla ve zorlu olduğu görülmektedir. Çünkü erkekler, duyarsızlaşma konusunda daha eğilimli oldukları için beraber çalıstıkları bireylere 
karşı katı duygulara sahip olabilirler. Eğitim düzeyine bakıldığında çok belirgin farkların olmadığ1 söylenebilir. Eğitim seviyesi yüksek olan kişinin hayattan beklentisi de yüksektir. İdealleri çoktur, kendine yüksek hedefler koyabilir. Fakat iş yerindeki rolüne yeterince hazırlanmazsa, ideallerinin gerçekle uyuşmaması hayal kırıklığına neden olabilir ve tükenmişlik yaşayabilir. Eğitim seviyesi daha düşük olan bireyin beklentileri yüksek olmadığı için idealleri ile başarıları arasındaki fark daha azdır (Abacı, 2004: 17-18).

Yaş faktörü ile tükenmişlik arasında yoğun bir ilişkiden söz edilebilir. Çalışma ortamında tükenmişlik sendromu, gençler arasında yüksek iken yaşlı bireyler arasında daha düşüktür. Çalışan bireyler yaşlandıkça daha tatminkar, istikrarlı ve tükenmişlik konusunda dayanıklı olmaya başlarlar. Gençlerin iş ile ilgili beklenti düzeyleri daha çok olduğundan çalışma hayatının ilk yıllarında tükenme ihtimalleri daha fazladır (Örmen, 1993: 12).

Birey, içsel nedenler haricinde örgütsel faktörlerin etkisiyle de tükenmişlik yaşayabilir. İş ortamında karşılaşılan insanlarla fazla zaman geçirilmesi, etkileşimin çok olması, müşterilerin çoğalması, birebir kurulan ilişkiler ve müşterilerin ağır sorunlarıyla uğraşmak tükenmişliğin seviyesini artırmaktadır (Torun, 1995: 11-12).

İş ortamında insanlarla ilgilenmek, sadece hizmet verilen kişileri kapsamaz. Çalışma arkadaşlarıyla ve yöneticilerle de temas halinde oluruz. Mesai arkadaşları, kişiyi destekleyebilecekleri gibi kişinin başarısına mani de olabilirler (Çağlıyan, 2007: 34).

Birey, yaptığı işten dolayı ödüllendirilmesi gerektiğine inandığı halde bu gerçekleşmiyorsa, örgüte sağlamış olduğu katkının dikkate alınmadığını düşünür. Bu da bireyin motivasyonunu ve performansını düşürür. Ödüllendirme açısından uyumsuzluğun nedeni, bireyin kazandığı başarılar karşısında maddi ödüllerin yetersiz kalmasıdır. Fakat çoğu kez bireyin mühim başarılarının görmezden gelinmesi ya da diğerleriyle eşit derecede ele alınmaması gibi sosyal yönden tatmin edilemeyen ödüllerin maddi ödüllerle kıyaslandığında çok daha önemli olduğu söylenebilir (Polatc1, 2007: 68-69).

\subsection{Tükenmişliği Önlemek İçin Kullanılan Yöntemler}

Tükenmişliği önlemek için kullanılan bireysel yöntemler şunlardır: Bireyin kendini iyi tanıması, kendini denetleyebilmesi, işinin zor yanlarını bilip riskleri hesaplayabilmesi, tükenmişliğinin farkına varması, strese neden olan faktörleri tanıması, değişime ayak uydurup rutinleri ortadan kaldırması, belli aralıklarla işine ara vermesi, tatile çıkması, gerektiğinde yardım veya destek alması, hobi edinmesi, hayır diyebilmesi, dinlenme süresini verimli 
kullanabilmesi, çalışma arkadaşlarıyla ilişkilerini ilerletmesi, ailesine zaman ayırması ve sağlığına dikkat etmesi gerekir (Demir, 1995).

Tükenmişliği önlemek amacıyla uygulanan örgütsel yöntemler şunlardır: Görevlerin, sorumlulukların ve yetkilerin açık ve net olması, yeni çalsşanlara oryantasyon eğitimlerinin verilmesi, etkin işgören planının yapılması, düzenli toplantılar yapılarak öneri ve eleştirilerin alınması, gelecekle alakalı daha gerçekçi programların hazırlanması, sorunların çıkar çıkmaz ele alınması, çevre koşullarının iyileştirilmesi, örgüt üyeleri arasında sözlü ve yazılı iletişimin kurulmasını sağlayarak sorunların tartışılabileceği ve bu tartışmaların sonucunda beyan edilen olumlu ya da olumsuz fikirlerin bedelinin ödetilmeyeceği bir ortamın yaratılması, performans değerlendirmesinin düzenli olarak yapılması, işgörenlerin sıkıntılı durumlarında yöneticilerinden yardım alabilmesi ve bireysel gereksinimlerinin karşılanmasına önem verilmesi, başarıların takdir edilmesi ve ödüllendirilmesi, sürekli eğitim olanaklarının sağlanması ve işgörenin alınan kararlara katılımının sağlanması (Izgar, 2003: 29).

\subsection{Havayolu Şirketlerinde Kabin Ekibi Çalışanları}

Kabin ekibi, uluslararası sivil havacilık kurallarını ve çalıştığ1 şirketin prosedürlerini yerine getirmek koşuluyla, uçuş operasyonunun başlangıcından sonuna kadar uçuş emniyetini ve yolcu konforunu sağlayan, gerekli eğitimleri almış, kabin amirinden ve kabin memurlarından oluşan ekip olarak ifade edilebilir.

Emniyet, uçuş operasyonlarında uygulanması gereken en önemli kural olup; emniyetin sağlanması tüm çalışanların birinci sorumluluğudur. Bu amaçla uluslararası sivil havacılık örgütleri, emniyet ile ilgili uyulması gereken kuralları ve standartları belirlemiştir. $\mathrm{Bu}$ örgütlere üye olan ülkelerin yerel otoriteleri (Türkiye'de Sivil Havacilk Genel Müdürlügü), belirlenen kural ve standartların havayolu şirketleri tarafından uygulanıp uygulanmadıklarını denetlemekle sorumludur. Kabin ekibi çalşanları da, emniyet ile ilgili kuralları ve prosedürleri bilmekten ve uygulamaktan, yönetmelikleri, genelgeleri ve duyuruları takip etmekten sorumludurlar. Aynı zamanda yolcuların isteklerini mevcut olanaklar ölçüsünde karşılamak, sorunlarına çözüm bulmak ve seyahatlerinden memnun kalmalarını sağlamak da yolcu konforu açısından oldukça önemlidir. 


\subsection{Kabin Ekibinin Görev ve Sorumlulukları}

Genellikle kabin ekiplerinin uçakta ikram hizmeti dışında yaptıkları işler ve aldıkları sorumluluklar bilinmemektedir. Kabin ekiplerinin başlıca görev ve sorumlulukları şunlardır: Uçağa gelindiğinde uçağın güvenlik ve temizlik kontrolünün yapılması, acil durumlarda lazım olabilecek malzemelerin kontrol edilmesi, ikram malzemelerinin eksiksiz olarak teslim alınması, yolcuların karşılanıp uğurlanması, yerde ve uçuş boyunca güvenlik tedbirlerinin alınması, hasta ya da yaralı yolcuya (uçakta doktor/hemşire yoksa) temel ilk yardımın uygulanması, acil durumlarda kaptanın komutlarına göre ilgili prosedürün uygulanması, uçuş esnasında kabinde tespit edilen arızaların teknik departmana bildirilmesi, emniyetsiz ya da riskli görülen durumları/olayların şirketin emniyet yönetim birimine rapor edilmesi, uçuş sonunda uçağın güvenlik kontrolünün yapılması.

\subsection{Kabin Ekibinin Çalışma Koşulları}

- Kabin ekiplerinin düzenli çalışma saatleri yoktur. Günün herhangi bir saatinde uçuşa gidebilirler. Çalışanlar, uyku ve istirahat saatlerini buna göre ayarlamak zorundadırlar.

- Kabin ekibi çalışanları için hafta sonu ya da bayram tatili kavramı yoktur. Bayramlarda ya da hafta sonlarında uçuşta veya yatı görevinde olabilirler.

- Uçuşların yoğun olması, uzun mesafeli uçuşlar ve yatı görevleri, kabin ekibi çalışanlarının uzun süre evden uzak kalmasına neden olabilir.

- Havayolu şirketinin ekip planlama birimi tarafından her uçuş görevi için farklı bir ekip oluşturulur. Çalışanlar, yatı görevi haricinde her zaman aynı ekiple uçuşa gitmezler. Özellikle eleman sayısı fazla olan şirketlerde beraber görev yapan ekip üyeleri, uzun süre denk gelmeyebilirler.

- Havayolu şirketlerinde uçuş programları genellikle aylık olarak yayımlanır. Örneğin; çalışan, iki ay sonrası için özel hayatıyla ilgili plan yapamaz. Ancak şirket tarafından uygun görülürse ileri bir tarih için boş gün talebinde bulunabilir.

- Çalışanların uçuş görevi haricinde nöbet görevleri vardır. Bu görev ev nöbeti ya da alan nöbeti şeklinde olabilir. Ev nöbetindeki çalısan, üniformasız bir şekilde evde bekler. Uçuş çantası, kıyafetleri ve evrakları hazırdır. Kişi, arandığında her an ulaşılabilir olmalıdır. Alan nöbetindeki çalışan ise üniformalı bir şekilde şirketin ofisinde/bekleme odasında hazır bulunur. Hastalanan veya mazereti sebebiyle uçuşa gidemeyecek durumda olan kabin ekibi üyesi olursa ekip tahsis birimi tarafindan nöbetçi kabin amiri/memuru ataması yapılır. Nöbet 
görevi, belirli bir saat aralı̆ı̆nı kapsar. Eğer nöbet görevinden herhangi bir uçuş verilmez ise çalışan boşa çıar.

- Kitalararası ya da uzun mesafeli bir uçuştan sonra varılan ülkede yatı yapacak olan kabin ekibi üyeleri, gidilen ülkenin zaman dilimine hemen adapte olamayabilirler. "Jetlag" adı verilen bu durumun yaşanması normaldir. Çünkü insan, vücudunu belirli bir zaman dilimine göre ayarlar ve o zaman dilimine göre yemek yeme, uyuma gibi yaşamsal faaliyetlerini gerçekleştirir. Örneğin; sabah uçakla Türkiye'den hareket edip Uzak Doğu’ya vardığımızda vücudumuz akşam olduğunu düşünür. Oysaki bulunduğumuz yerin saat dilimine göre gece olmuştur. Adaptasyon sürecinde yerel saatin düzenine uygun olmayan yeme ve uyuma isteği, sindirim problemi, fiziksel ve mental açıdan performans düşüklüğü yaşanabilir.

- Uçağın arızalanması, yolcunun rahatsızlanması, hava koşulları gibi nedenlerle çalışanların mesai süreleri uzayabilir.

- Uçaklar, yüksek irtifalarda uçtukları için kabin ekipleri yüksek oranda radyasyona maruz kalırlar.

- Çalısanlar, özellikle kısa mesafeli uçuşlarda ikram servisinin hazırlanması ve yolcuya sunulması açısından zaman baskısı yaşayabilirler.

- Servis esnasında sürekli eğilip kalkmak ve servis arabalarını çekmek, çalışanlarda bel ve boyun fitığına neden olabilir. Çalışanlar, uzun süre ayakta olduklan için varis oluşabilir. Basınç probleminden dolayı kulak rahatsızlıkları yaşanabilir. Kabin ekibi çalışanları, görevleri gereği farklı coğrafi bölgelere seyahat edip farklı yaşam alanlarındaki insanlarla temas ettikleri için çeşitli bulaşıcı hastalıklara yakalanma olasılıkları vardır. Çalışanlarda rastlanan bir diğer sağlik problemi de vertigodur.

- Kabin ekibi, gecikmeli uçuşta ya da yolcu talebinin karşılanamaması durumunda yolcunun tepkisine ya da hakaretine maruz kalabilir.

- Kabin ekibi çalışanları, uçma korkusu olan, uçuş kurallarına uyma konusunda sıkıntı çıkaran, alkollü, uçakta sigara içen ya da içmek isteyen, sabırsız, agresif gibi her türlü yolcu profiliyle karşılaşabilirler.

Bu çalışma koşullarından bazıları, kabin ekibi çalışanlarını ruhsal ve fiziksel olarak olumsuz yönde etkileyebileceği gibi tükenmişliğe de yol açabilir. 


\section{BULGULAR}

\subsection{Araştırmanın Amacı ve Önemi}

$\mathrm{Bu}$ araştırmada, havayolu şirketlerinin personel sayısında önemli bir paya sahip olan kabin ekibi çalşanlarının tükenmişlik düzeylerini belirlemek, tükenmişlik düzeylerinin demografik özelliklere ve mesleki deneyimlere göre değişip değissmediğini saptamak ve varsa konuyla ilgili sorunları ortaya çıkarmak amaçlanmıştır. Ülkemizde tükenmişlik kavramı ile ilgili araştırmalar daha çok sağlık çalışanlarına, eğitimcilere ve emniyet birimi çalışanlarına yönelik yapılmaktadır. Kabin ekibi üyelerine yönelik yapılan çalısmaların sayısı oldukça sınırlıdır. Bunun en önemli nedeni çalışanlara ulaşmanın zorluğu olarak gösterilebilir.

Yoğun çalşsma temposu içinde olan ve kendilerinden yüksek performans göstermeleri beklenen kabin ekibi çalışanlarının yaptıkları işe olan bağlllı̆̆ son derece önemlidir. Dolayısıyla bu çalışma, tükenmişliğe neden olabilecek faktörlerin bilinmesi ve gereken tedbirlerin alınması açısından da yöneticilere faydalı olacaktır.

\subsection{Araştırmanın Evreni ve Örneklemi}

Araştırmanın evrenini Antalya ilinde faaliyet gösteren özel bir havayolu şirketinin çalışanları oluşturmaktadır. 2020 yılı itibarıyla şirketin Antalya kabin hizmetleri başkanlığında görev yapan kabin ekibi üyelerinin toplam sayısı 227'dir. Anketlerin geri dönüş sayıs1 126 olup, anketlerin geri dönüş oranı \%98,41'dir. Geri dönen anketlerin 2 tanesi eksik doldurulduğundan 124 adet anket, araştırmanın analizlerine dahil edilmiştir.

Belirli evrenler için kabul edilebilir örnek büyüklükleri tablosundaki değerler ile bu çalışmadaki evren-örneklem büyüklügü karşılaştırılmış ve örneklem sayısının yeterli olduğu görülmüştür (Altunışık, Coşkun, Bayraktaroğlu ve Yıldırım, 2010: 135).

\subsection{Veri Toplama Arac1}

$\mathrm{Bu}$ araştırmanın kapsamında veri elde etmek amacıyla "Kişisel Bilgi Formu" ile birlikte Maslach ve Jackson (1986) tarafından geliştirilen ve Ergin (1992) tarafindan Türkçeye uyarlanan "Maslach Tükenmişlik Ölçeği” olmak üzere iki bölümden oluşan bir anket formu hazırlanmıştır. Kişisel Bilgi Formu, ankete katılanların cinsiyeti, yaşı, medeni durumu, çocuk 
durumu, eğitim durumu, sektör ve şirket deneyimi ile çalışma statüsüne ilişkin bilgilerini toplamak amacıyla toplam 8 maddeden oluşmaktadır.

Maslach ve Jackson'in geliştirdiği ölçek toplam 22 maddeden oluşmaktadır ve 3 alt boyutta değerlendirilmektedir. Duygusal tükenme alt boyutunda 9 madde, düşük kişisel başarı alt boyutunda 5 madde ve duyarsılaşma alt boyutunda ise 5 soru yer almaktadır (Maslach ve Jackson, 1986).

Tablo 1: Maslach Tükenmişlik Ölçeği Alt Boyutları ve Maddeleri

\begin{tabular}{l|c|c}
\hline Alt Boyut & Madde Sayısı & Madde Numaraları \\
\hline Duygusal Tükenme & 9 & 1., 2., 3., 6., 8., 13., 14.,16. ve 20. sorular \\
\hline Duyarsızlaşma & 5 & 5., 10., 11., 15. ve 22. sorular \\
\hline Düşük Kişisel Başarı & 8 & 4., 7., 9., 12., 17., 18.,19. ve 21. sorular
\end{tabular}

\subsection{Araştırmanın Hipotezleri}

H1: Tükenmişlik, cinsiyete göre anlamlı düzeyde farklılaşmaktadır.

H2: Tükenmişlik, yaş gruplarına göre anlamlı düzeyde farklılaşmaktadır.

H3: Tükenmişlik, medeni duruma göre anlamlı düzeyde farklılaşmaktadır.

H4: Tükenmişlik, çalışanın çocuğu olup olmamasına göre anlamlı düzeyde farklılaşmaktadır.

H5: Tükenmişlik, eğitim düzeyine göre anlamlı düzeyde farklılaşmaktadır.

H6: Tükenmişlik, sektör deneyimine göre anlamlı düzeyde farklılaşmaktadır.

H7: Tükenmişlik, şirketteki deneyime göre anlamlı düzeyde farklılaşmaktadır.

H8: Tükenmişlik, çalışma statüsüne (unvanına) göre anlamlı düzeyde farklılaşmaktadır.

\subsection{Verilerin Analizi}

Veriler, IBM SPSS V23 ile analiz edilmiş olup ikili gruplara göre normal dağılan verilerin karşılaştırılmasında bağımsız iki örnek t testi kullanılmıştır. Üç ve üzeri gruplara göre normal dağılan verilerin karşılaştırılmasında tek yönlü varyans analizi kullanılmış olup çoklu karşılaştırmalar Duncan ve Tamhane’s T2 testleriyle gerçekleştirilmiştir. Doğrulayıcı faktör analizinde IBM SPSS AMOS V24 programından yararlanılmıştır. Doğrulayıc1 faktör analizinde birinci düzey DFA kullanılmıştır. Hesaplama yöntemi olarak Maximum Likelihood hesaplama yöntemi kullanılmıştır. Analiz sonuçları nicel veriler için ortalama \pm s. sapma ve ortanca (minimum - maksimum) şeklinde sunulmuştur. Önem düzeyi $\mathrm{p}<0,050$ olarak 
alınmıştır. Çalışmada ölçeklerin güvenilirliğini ölçmek amacıyla Cronbach's Alpha katsayısı kullanılmışır.

Tablo 2: Tükenmişlik Güvenilirlik Analizi

\begin{tabular}{l|c|c}
\hline Değişkenler & Madde Sayısı & Cronbach's Alpha ( $\boldsymbol{\alpha})$ \\
\hline Duygusal Tükenme Alt Boyutu & 9 & 0,952 \\
\hline Duyarsızlaşma Alt Boyutu & 5 & 0,938 \\
\hline Düşük Kişisel Başarı Alt Boyutu & 8 & 0,918
\end{tabular}

Tablo 2 incelendiğinde tükenmişlik ölçeği alt boyutlar1 için $\alpha>0,80$ 'nin üzerinde olduğu tespit edilmiştir. Bulunan değerlere göre araştırmada kullanılan ölçekler yüksek düzeyde güvenilirliğe sahiptir.

\subsection{Demografik Değişkenlere İlişkin Bulgular}

Katılımcıların cinsiyeti, yaşı, medeni durumu, çocuk durumu, eğitim durumu, havacılık sektöründe mesleki deneyimi, çalışmakta oldukları şirketteki mesleki deneyimi, çalışma statüsü gibi özelliklerinin tespit edilmesi amaciyla istatistiksel verilerden yararlanılmıştır.

Tablo 3: Demografik Değişkenlere Ait Frekans Dağılımı

\begin{tabular}{|c|c|c|}
\hline & Frekans (n) & Yüzde $(\%)$ \\
\hline \multicolumn{3}{|l|}{ Cinsiyet } \\
\hline Kadın & 67 & 54 \\
\hline Erkek & 57 & 46 \\
\hline \multicolumn{3}{|l|}{ Yaş } \\
\hline $18-25$ & 49 & 40,3 \\
\hline $26-35$ & 50 & 42,7 \\
\hline $36-45$ & 20 & 16,1 \\
\hline 46 ve üzeri & 5 & 4 \\
\hline \multicolumn{3}{|l|}{ Medeni durum } \\
\hline Evli & 40 & 32,3 \\
\hline Bekar & 69 & 55,6 \\
\hline \multirow[t]{2}{*}{ Boşanmış } & 15 & 12,1 \\
\hline & Frekans (n) & Yüzde (\%) \\
\hline \multicolumn{3}{|l|}{ Çocuk durumu } \\
\hline Var & 31 & 25 \\
\hline Yok & 93 & 75 \\
\hline
\end{tabular}




\section{Eğitim durumu}

\begin{tabular}{lcc} 
Lise & 48 & 38,7 \\
Ön lisans & 28 & 22,6 \\
Lisans & 47 & 37,9 \\
Yüksek lisans ve üzeri & 1 & 0,8 \\
\hline Sektör deneyimi & & \\
1-4 yll & 55 & 44,4 \\
5-8yıl & 23 & 18,5 \\
9-12 y1l & 31 & 25 \\
13 yll ve üzeri & 15 & 12,1 \\
Şirket deneyimi & & \\
1-4 yll & 57 & 46 \\
5-8 yll & 33 & 26,6 \\
$9-12$ yll & 20 & 16,1 \\
13 yıl ve üzeri & 14 & 11,3 \\
Ķalı̧̧ma statüsü & & 64,5 \\
Kabin memuru & 80 & 35,5 \\
\hline Kabin amiri & 44 & $\mathbf{1 0 0}$ \\
\hline Toplam & $\mathbf{1 2 4}$ & \\
\hline
\end{tabular}

Tablo 3'e bakıldığında, katılımcıların \%54'ünün kadın, \%42,7'sinin 26-35 yaş aralığında, \%55,6'sının bekar, \%75'inin çocuğu olmadığı, \%38,7'sinin eğitim durumunun lise, \%44,4'ünün sektör deneyiminin 1-4 yll, \%46'sının şirket deneyiminin 1-4 yıl olduğu ve \%64,5’inin çalışma statüsünün kabin memuru olduğu görülmektedir.

\subsection{Birinci Düzey Doğrulayıcı Faktör Analizi}

Duygusal tükenme alt boyutu 9 maddeden, duyarsızlaşma alt boyutu 5 maddeden ve düşük kişisel başarı alt boyutu 8 maddeden oluşmak üzere toplamda 22 maddeden oluşan 3 faktörlü birinci düzey doğrulayıcı faktör analizi yapılmıştır. Analiz verilerine ilişkin veriler Tablo 4'te verilmiştir. 
Tablo 4: Tükenmişlik Ölçeği için Birinci Düzey Doğrulayıcı Faktör Analizi

\begin{tabular}{|c|c|c|c|c|c|c|c|c|}
\hline & & & $\beta^{0}$ & $\beta^{1}$ & SH & Test İst. & $\mathrm{p}$ & $\mathbf{R}^{2}$ \\
\hline Soru 1 & $<---$ & DT & 0,961 & 1,198 & 0,063 & 18,893 & $<0,001$ & 0,923 \\
\hline Soru 2 & $<---$ & DT & 0,942 & 1,16 & 0,065 & 17,792 & $<0,001$ & 0,887 \\
\hline Soru 3 & $<---$ & DT & 0,85 & 0,982 & 0,071 & 13,767 & $<0,001$ & 0,723 \\
\hline Soru 6 & $<---$ & DT & 0,906 & 1,143 & 0,071 & 15,999 & $<0,001$ & 0,821 \\
\hline Soru 8 & $<---$ & DT & 0,964 & 1,263 & 0,066 & 19,135 & $<0,001$ & 0,93 \\
\hline Soru 13 & $<---$ & DT & 0,87 & 1,074 & 0,074 & 14,495 & $<0,001$ & 0,757 \\
\hline Soru 14 & $<--$ & DT & 0,81 & 0,859 & 0,069 & 12,466 & $<0,001$ & 0,656 \\
\hline Soru 16 & $<---$ & DT & 0,841 & 0,922 & 0,069 & 13,428 & $<0,001$ & 0,707 \\
\hline \multirow[t]{2}{*}{ Soru 20} & $<---$ & DT & 0,893 & 1 & & & & 0,797 \\
\hline & & & $\beta^{0}$ & $\beta^{1}$ & SH & Test İst. & $\mathrm{p}$ & $\mathbf{R}^{2}$ \\
\hline Soru 21 & $<--$ & $\mathrm{KBD}$ & 0,601 & 1 & & & & 0,361 \\
\hline Soru 19 & $<---$ & KBD & 0,924 & 2,51 & 0,324 & 7,757 & $<0,001$ & 0,854 \\
\hline Soru 18 & $<---$ & KBD & 0,706 & 1,5 & 0,23 & 6,521 & $<0,001$ & 0,498 \\
\hline Soru 17 & $<---$ & KBD & 0,832 & 1,881 & 0,229 & 8,198 & $<0,001$ & 0,692 \\
\hline Soru 12 & $<---$ & $\mathrm{KBD}$ & 0,741 & 1,857 & 0,275 & 6,751 & $<0,001$ & 0,55 \\
\hline Soru 9 & $<---$ & KBD & 0,693 & 1,411 & 0,219 & 6,436 & $<0,001$ & 0,481 \\
\hline Soru 7 & $<---$ & KBD & 0,757 & 1,782 & 0,26 & 6,847 & $<0,001$ & 0,572 \\
\hline Soru 4 & $<---$ & $\mathrm{KBD}$ & 0,823 & 1,858 & 0,258 & 7,198 & $<0,001$ & 0,677 \\
\hline Soru 5 & $<---$ & $\mathrm{D}$ & 0,874 & 0,956 & 0,067 & 14,306 & $<0,001$ & 0,764 \\
\hline Soru 10 & $<---$ & $\mathrm{D}$ & 0,84 & 1,004 & 0,077 & 13,119 & $<0,001$ & 0,705 \\
\hline Soru 11 & $<---$ & $\mathrm{D}$ & 0,873 & 1,092 & 0,077 & 14,26 & $<0,001$ & 0,762 \\
\hline Soru 15 & $<---$ & $\mathrm{D}$ & 0,866 & 0,973 & 0,07 & 14,001 & $<0,001$ & 0,75 \\
\hline Soru 22 & $<---$ & $\mathrm{D}$ & 0,893 & 1 & & & & 0,798 \\
\hline
\end{tabular}

$\beta^{0}:$ Standart katsayı; $\beta^{1}$ : Standartlaştırllmamış katsayı; SH: Standart Hata

Soru 1'e ait standart olmayan yol katsayısı 1,198 olarak elde edilmiştir ve elde edilen katsayı istatistiksel olarak anlamlıdır $(\mathrm{p}<0,001)$. İlgili maddeye ait standart yol katsayısı ise 0,961 olarak bulunmuştur.

Soru 2'ye ait standart olmayan yol katsayıs1 1,16 olarak elde edilmiştir ve elde edilen katsayı istatistiksel olarak anlamlıdır $(\mathrm{p}<0,001)$. İlgili maddeye ait standart yol katsayısı ise 0,942 olarak bulunmuştur.

Soru 3'e ait standart olmayan yol katsayısı 0,982 olarak elde edilmiştir ve elde edilen katsayı istatistiksel olarak anlamlıdır $(\mathrm{p}<0,001)$. İlgili maddeye ait standart yol katsayısı ise 0,85 olarak bulunmuştur.

Soru 6'ya ait standart olmayan yol katsayıs1 1,143 olarak elde edilmiştir ve elde edilen katsayı istatistiksel olarak anlamlıdır $(\mathrm{p}<0,001)$. İlgili maddeye ait standart yol katsayısı ise 0,906 olarak bulunmuştur. 
Soru 8'e ait standart olmayan yol katsayısı 1,263 olarak elde edilmiştir ve elde edilen katsayı istatistiksel olarak anlamlıdır $(\mathrm{p}<0,001)$. Ilgili maddeye ait standart yol katsayıs ise 0,964 olarak bulunmuştur.

Soru 13'e ait standart olmayan yol katsayıs1 1,074 olarak elde edilmiştir ve elde edilen katsayı istatistiksel olarak anlamlıdır $(\mathrm{p}<0,001)$. İlgili maddeye ait standart yol katsayıs ise 0,87 olarak bulunmuştur.

Soru 14'e ait standart olmayan yol katsayısı 0,859 olarak elde edilmiştir ve elde edilen katsayı istatistiksel olarak anlamlıdır $(p<0,001)$. Ilgili maddeye ait standart yol katsayısı ise 0,81 olarak bulunmuştur.

Soru 16'ya ait standart olmayan yol katsayısı 0,922 olarak elde edilmiştir ve elde edilen katsayı istatistiksel olarak anlamlıdır $(\mathrm{p}<0,001)$. İlgili maddeye ait standart yol katsayısı ise 0,841 olarak bulunmuştur.

Soru 20'ye ait standart olmayan yol katsayıs1 1 olarak elde edilmiştir ve elde edilen katsayı istatistiksel olarak anlamlıdır $(\mathrm{p}<0,001)$. Ilgili maddeye ait standart yol katsayıs ise 0,893 olarak bulunmuştur.

Soru 21'e ait standart olmayan yol katsayısı 1 olarak elde edilmiştir ve elde edilen katsayı istatistiksel olarak anlamlıdır $(\mathrm{p}<0,001)$. İlgili maddeye ait standart yol katsayısı ise 0,601 olarak bulunmuştur.

Soru 19'a ait standart olmayan yol katsayıs1 2,51 olarak elde edilmiştir ve elde edilen katsayı istatistiksel olarak anlamlıdır $(\mathrm{p}<0,001)$. İgili maddeye ait standart yol katsayıs ise 0,924 olarak bulunmuştur.

Soru 18'e ait standart olmayan yol katsayısı 1,5 olarak elde edilmiştir ve elde edilen katsayı istatistiksel olarak anlamlıdır $(\mathrm{p}<0,001)$. İlgili maddeye ait standart yol katsayısı ise 0,706 olarak bulunmuştur.

Soru 17'ye ait standart olmayan yol katsayıs1 1,881 olarak elde edilmiştir ve elde edilen katsayı istatistiksel olarak anlamlıdır $(\mathrm{p}<0,001)$. İlgili maddeye ait standart yol katsayısı ise 0,832 olarak bulunmuştur.

Soru 12'ye ait standart olmayan yol katsayısı 1,857 olarak elde edilmiştir ve elde edilen katsayı istatistiksel olarak anlamlıdır $(\mathrm{p}<0,001)$. İlgili maddeye ait standart yol katsayısı ise 0,741 olarak bulunmuştur.

Soru 9'a ait standart olmayan yol katsayısı 1,411 olarak elde edilmiştir ve elde edilen katsayı istatistiksel olarak anlamlıdır $(\mathrm{p}<0,001)$. Ilgili maddeye ait standart yol katsayısı ise 0,693 olarak bulunmuştur. 
Soru 7'ye ait standart olmayan yol katsayısı 1,782 olarak elde edilmiştir ve elde edilen katsayı istatistiksel olarak anlamlıdır $(\mathrm{p}<0,001)$. Ilgili maddeye ait standart yol katsayıs ise 0,757 olarak bulunmuştur.

Soru 4'e ait standart olmayan yol katsayısı 1,858 olarak elde edilmiştir ve elde edilen katsayı istatistiksel olarak anlamlıdır $(\mathrm{p}<0,001)$. İlgili maddeye ait standart yol katsayıs ise 0,823 olarak bulunmuştur.

Soru 5'e ait standart olmayan yol katsayıs1 0,956 olarak elde edilmiştir ve elde edilen katsayı istatistiksel olarak anlamlıdır $(\mathrm{p}<0,001)$. Ilgili maddeye ait standart yol katsayısı ise 0,874 olarak bulunmuştur.

Soru 10'a ait standart olmayan yol katsayısı 1,004 olarak elde edilmiştir ve elde edilen katsayı istatistiksel olarak anlamlıdır $(\mathrm{p}<0,001)$. İlgili maddeye ait standart yol katsayısı ise 0,84 olarak bulunmuştur.

Soru 11'e ait standart olmayan yol katsayıs1 1,092 olarak elde edilmiştir ve elde edilen katsayı istatistiksel olarak anlamlıdı $(\mathrm{p}<0,001)$. Ilgili maddeye ait standart yol katsayıs ise 0,873 olarak bulunmuştur.

Soru 15'e ait standart olmayan yol katsayıs1 0,973 olarak elde edilmiştir ve elde edilen katsayı istatistiksel olarak anlamlıdır $(\mathrm{p}<0,001)$. İlgili maddeye ait standart yol katsayısı ise 0,866 olarak bulunmuştur.

Soru 22'ye ait standart olmayan yol katsayısı 1 olarak elde edilmiştir ve elde edilen katsayı istatistiksel olarak anlamlıdır $(\mathrm{p}<0,001)$. Ilgili maddeye ait standart yol katsayıs ise 0,893 olarak bulunmuştur.

\subsection{Uyum İyiliği İndeksleri}

Uyum indekslerinden hangilerinin rapor edilmesi gerektiği konusunda birçok araştırmacı tarafindan farklı öneriler getirilmiştir. Garver ve Mentzer (1999); RMSEA, CFI ve TLI, McDonald ve Ho (2002); CFI, GFI, NFI ve TLI, Brown (2006); RMSEA, SRMR, CFI ve TLI, Iacobucci (2010); CFI ve SRMR uyum indekslerinin rapor edilmesini önermektedir. Gerbing ve Anderson (1992) ise, araştırmacıların amaçları doğrultusunda farklı uyum indekslerini rapor edebileceklerini dile getirmektedir (İlhan ve Çetin, 2014: 31). 
Tablo 5: YEM'de Kullanılan Uyum İyiliği İndeksleri ve Eşik Değerleri

\begin{tabular}{lll}
\hline Uyum İndeksleri & İyi Uyum & Kabul Edilebilir Uyum \\
\hline $\mathrm{X}^{2} / \mathrm{df}$ & $<3$ & $3<\left(\mathrm{X}^{2} / \mathrm{df}\right)<5$ \\
RMSEA & $<0,05$ & $<0,08$ \\
SRMR & $<0,05$ & $<0,08$ \\
CFI & $>0,95$ & $>0,90$ \\
TLI & $>0,95$ & $>0,90$ \\
IFI & $>0,95$ & $>0,90$ \\
GFI & $>0,95$ & $>0,90$ \\
\hline
\end{tabular}

$\mathrm{X}^{2}$ : Ki Kare, df: Degree of Freedoom, RMSEA: Root Mean Square Error of Approximation, SRMR: Standardized Root Mean Square Residual, CFI: Comparative Fit Index, TLI: Tucker Lewis Index, IFI: Incremental Fit Index, GFI: Goodness of Fit Index.

Kaynak: (Byme, 2016), (Gürbüz ve Şahin, 2018), (Hu ve Bentler, 1998), (Kline, 2016), (akt. Gürbüz, 2019: 34).

Yapılan analiz sonucunda model uyum değerleri incelenmiş ve e3 ile e8, e10 ile e16 ve e14 ile e17 arasında kovaryans yapısı önerilmiştir. İlgili yapı oluşturulup model çözümlendiğinde X2/df=1,830 (iyi uyum), $\mathrm{RMSEA}=0,076$ (kabul edilebilir uyum), SRMR = 0,0387 (iyi uyum), CFI= 0,946 (kabul edilebilir uyum), TLI= 0,939 (kabul edilebilir uyum), $\mathrm{IFI}=0,946$ (kabul edilebilir uyum) ve GFI= 0,792 olarak elde edilmiştir. 


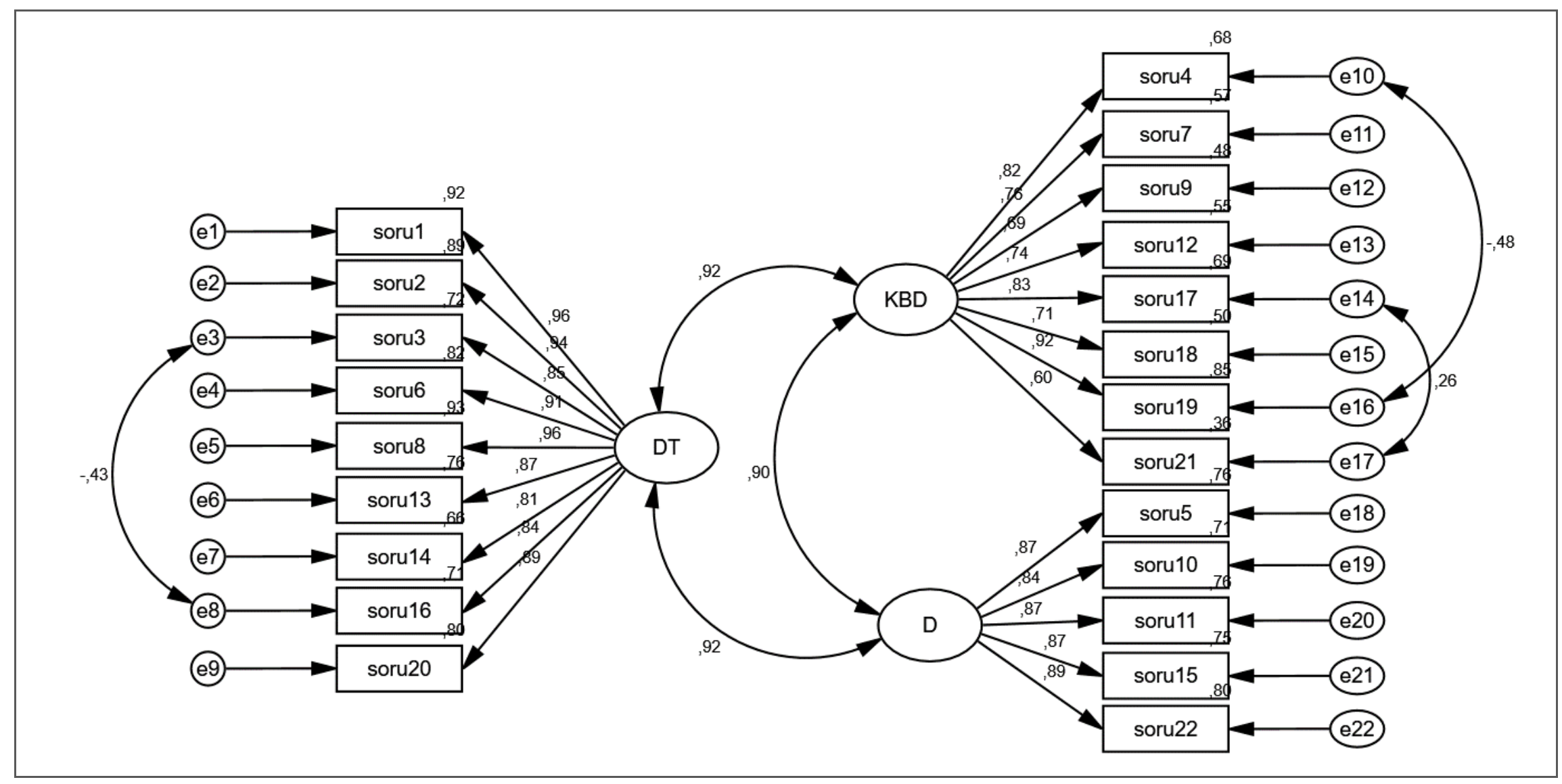

Şekil 1. Standartlaştımlmıs yol katsayular 
Serdar KIZILCAN, Güten DEMIRAL

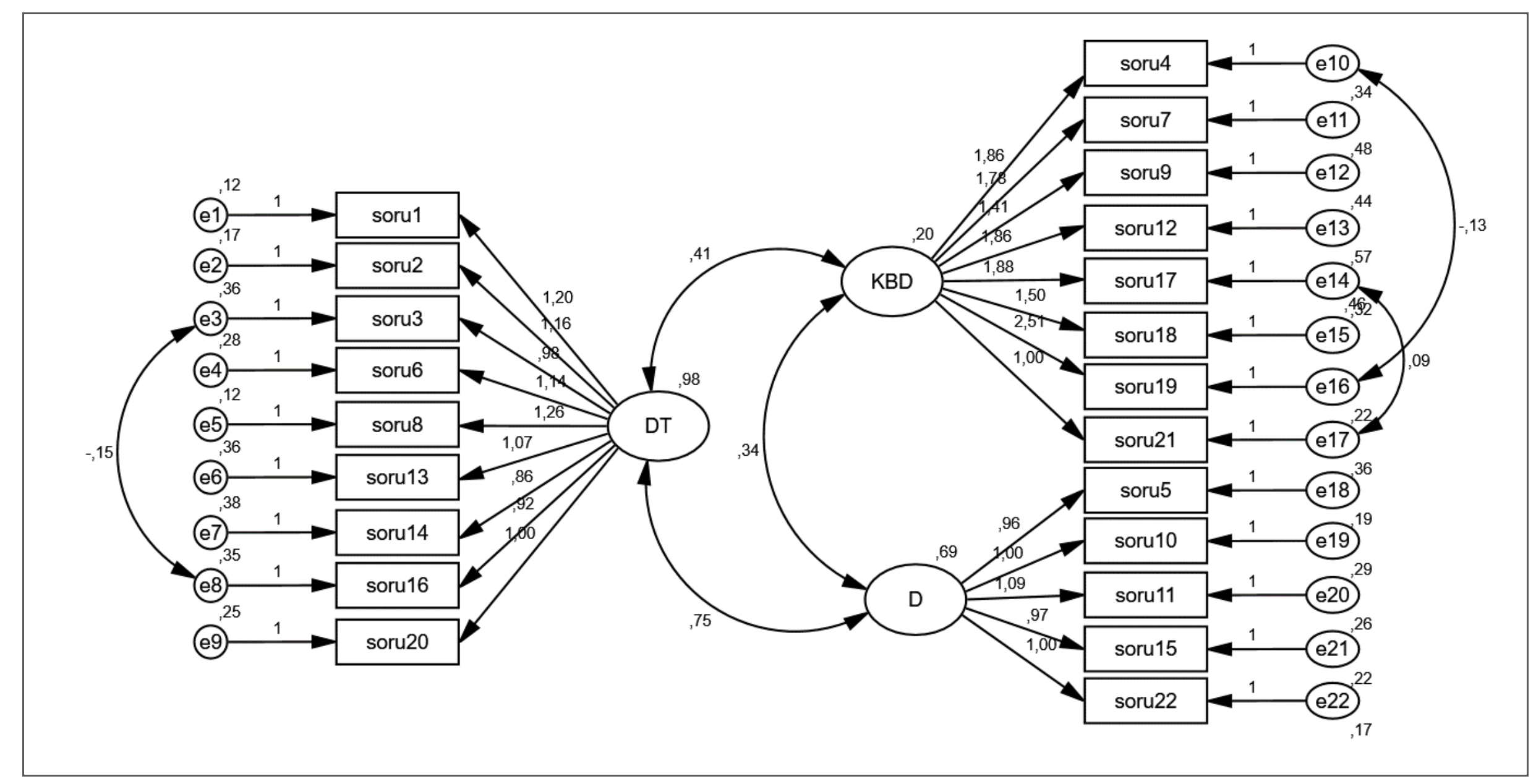

Şekil 2. Standartlaştırlmamıs yol katsaynlar

Year/Yil 2021, Volume/Cilt 2 Issue/Say1 1,

$17-46$ 
Tablo 6: Demografik Özelliklere Göre Tükenmişlik Ölçeğinin Karşılaştırılması

\begin{tabular}{|c|c|c|c|c|c|c|}
\hline & \multicolumn{2}{|c|}{ Duygusal tükenme } & \multicolumn{2}{|c|}{ Duyarsılaşma } & \multicolumn{2}{|c|}{ Kişisel başarı düşüklüğü } \\
\hline & Ort. \pm s. sapma & Ort. (min. - maks.) & Ort. \pm s. sapma & Ort. (min. - maks.) & Ort. \pm s. sapma & Ort. (min. - maks.) \\
\hline \multicolumn{7}{|l|}{ Cinsiyet } \\
\hline Kadin & $3,62 \pm 1,06$ & $4,00(1,67-5,00)$ & $3,29 \pm 0,85$ & $3,40(2,00-4,40)$ & $3,82 \pm 0,71$ & $4,13(2,25-5,00)$ \\
\hline Erkek & $3,52 \pm 1,10$ & $4,11(1,67-4,89)$ & $3,37 \pm 0,89$ & $3,40(1,60-5,00)$ & $3,70 \pm 0,93$ & $4,00(1,88-4,88)$ \\
\hline Test istatistiği & \multicolumn{2}{|c|}{$\mathrm{t}=0,489$} & \multicolumn{2}{|c|}{$\mathrm{t}=-0,486$} & \multicolumn{2}{|c|}{$\mathrm{t}=0,790$} \\
\hline $\mathrm{p}$ & \multicolumn{2}{|c|}{0,625} & \multicolumn{2}{|c|}{0,628} & \multicolumn{2}{|c|}{0,431} \\
\hline \multicolumn{7}{|l|}{ Yaş } \\
\hline $18-25$ & $4,22 \pm 0,73^{a}$ & $4,33(1,89-5,00)$ & $3,71 \pm 0,72^{a}$ & $4,00(2,20-4,80)$ & $4,21 \pm 0,48^{a}$ & $4,38(2,88-4,88)$ \\
\hline $26-35$ & $3,33 \pm 1,06^{b}$ & $3,06(1,67-4,89)$ & $3,19 \pm 0,90^{\mathrm{b}}$ & $2,80(1,60-5,00)$ & $3,67 \pm 0,76^{b}$ & $3,50(2,38-4,88)$ \\
\hline 36 ve üzeri & $2,79 \pm 0,95^{\mathrm{b}}$ & $2,33(1,67-4,89)$ & $2,85 \pm 0,73^{\mathrm{b}}$ & $2,60(2,00-4,20)$ & $3,09 \pm 0,93^{c}$ & $2,75(1,88-5,00)$ \\
\hline Test istatistiği & \multicolumn{2}{|c|}{$\mathrm{F}=26,363$} & \multicolumn{2}{|c|}{$\mathrm{F}=12,837$} & \multicolumn{2}{|c|}{$\mathrm{F}=21,087$} \\
\hline $\mathrm{p}$ & \multicolumn{2}{|c|}{$<0,001$} & \multicolumn{2}{|c|}{$<0,001$} & \multicolumn{2}{|c|}{$<0,001$} \\
\hline \multicolumn{7}{|l|}{ Medeni Durum } \\
\hline Evli & $3,40 \pm 1,15$ & $3,39(1,67-4,89)$ & $3,25 \pm 0,94$ & $2,80(2,00-5,00)$ & $3,75 \pm 0,79$ & $3,75(2,38-5,00)$ \\
\hline Bekar & $3,63 \pm 1,04$ & $4,00(1,89-5,00)$ & $3,32 \pm 0,82$ & $3,40(1,60-4,40)$ & $3,73 \pm 0,84$ & $4,13(1,88-4,88)$ \\
\hline Boşanmiş & $3,76 \pm 0,97$ & $4,33(2,11-4,89)$ & $3,55 \pm 0,87$ & $4,00(2,00-4,80)$ & $3,98 \pm 0,78$ & $4,38(2,63-4,88)$ \\
\hline Test istatistiği & \multicolumn{2}{|c|}{$\mathrm{F}=0,874$} & \multicolumn{2}{|c|}{$\mathrm{F}=0,639$} & \multicolumn{2}{|c|}{$\mathrm{F}=0,596$} \\
\hline $\mathrm{p}$ & \multicolumn{2}{|c|}{0,420} & \multicolumn{2}{|c|}{0,529} & \multicolumn{2}{|c|}{0,552} \\
\hline \multicolumn{7}{|l|}{ Çocuk Durumu } \\
\hline Var & $3,55 \pm 1,09$ & $4,11(1,67-4,89)$ & $3,41 \pm 0,97$ & $4,00(2,00-5,00)$ & $3,93 \pm 0,79$ & $4,25(2,38-5,00)$ \\
\hline Yok & $3,58 \pm 1,07$ & $3,78(1,89-5,00)$ & $3,30 \pm 0,83$ & $3,20(1,60-4,80)$ & $3,71 \pm 0,82$ & $3,88(1,88-4,88)$ \\
\hline Test istatistiği & \multicolumn{2}{|c|}{$\mathrm{t}=-0,118$} & \multicolumn{2}{|c|}{$\mathrm{t}=0,586$} & \multicolumn{2}{|c|}{$\mathrm{t}=1,291$} \\
\hline $\mathrm{p}$ & \multicolumn{2}{|c|}{0,906} & \multicolumn{2}{|c|}{0,559} & \multicolumn{2}{|c|}{0,199} \\
\hline Eğitim Durumu & & & & & & \\
\hline Lise & $3,54 \pm 1,09$ & $4,17(1,67-4,89)$ & $3,32 \pm 0,91$ & $3,60(1,60-5,00)$ & $3,74 \pm 0,91$ & $4,06(1,88-5,00)$ \\
\hline Önlisans & $3,23 \pm 1,13$ & $2,89(1,89-4,89)$ & $3,15 \pm 0,93$ & $2,70(2,00-4,80)$ & $3,68 \pm 0,81$ & $3,50(1,88-4,88)$ \\
\hline Lisans ve üzeri & $3,80 \pm 0,98$ & $4,17(2,11-5,00)$ & $3,44 \pm 0,78$ & $3,90(2,40-4,40)$ & $3,85 \pm 0,73$ & $4,25(2,13-4,88)$ \\
\hline Test istatistiği & & 2,665 & & 0,980 & & 0,410 \\
\hline $\mathrm{p}$ & & 074 & & 378 & & 665 \\
\hline
\end{tabular}

Year/Y1l 2021, Volume/Cilt 2 Issue/Say1 1,

$$
17-46
$$


t: Bağımsız iki örnek t test istatistiği, F: Tek yönlü varyans analizi test istatistiği, a-c: Aynı harfe sahip gruplar arasında fark yoktur.

\begin{tabular}{|c|c|c|c|c|c|c|}
\hline & \multicolumn{2}{|c|}{ Duygusal tükenme } & \multicolumn{2}{|c|}{ Duyarsızlaşma } & \multicolumn{2}{|c|}{ Kişisel başarı düşüklüğü } \\
\hline & Ort. \pm s. sapma & Ort. (min. - maks.) & Ort. \pm s. sapma & Ort. (min. - maks.) & Ort. \pm s. sapma & Ort. (min. - maks.) \\
\hline \multicolumn{7}{|l|}{ Sektör Deneyimi } \\
\hline 1-4 yil & $4,09 \pm 0,86^{a}$ & $4,33(1,89-5,00)$ & $3,67 \pm 0,77 a$ & $4,00(2,20-5,00)$ & $4,14 \pm 0,55^{\mathrm{a}}$ & $4,38(2,63-4,88)$ \\
\hline $5-8 y 11$ & $3,40 \pm 1,02^{b}$ & $3,33(1,89-4,89)$ & $3,20 \pm 0,86^{b}$ & $2,80(2,20-4,80)$ & $3,70 \pm 0,79 \mathrm{ab}$ & $3,63(1,88-4,88)$ \\
\hline $9-12$ y1l & $3,19 \pm 1,13^{b}$ & $2,67(1,67-4,89)$ & $3,08 \pm 0,88^{b}$ & $2,60(1,60-4,40)$ & $3,45 \pm 0,92^{\mathrm{b}}$ & $3,13(1,88-4,88)$ \\
\hline 13 yil ve üzeri & $2,73 \pm 0,84^{b}$ & $2,56(1,67-4,22)$ & $2,79 \pm 0,73^{b}$ & $2,60(2,00-4,20)$ & $3,17 \pm 0,84^{b}$ & $3,00(2,00-5,00)$ \\
\hline Test istatistiği & \multicolumn{2}{|c|}{$\mathrm{F}=12,770$} & \multicolumn{2}{|c|}{$\mathrm{F}=6,518$} & \multicolumn{2}{|c|}{$\mathrm{F}=9,917$} \\
\hline $\mathrm{p}$ & \multicolumn{2}{|c|}{$<0,001$} & \multicolumn{2}{|c|}{$<0,001$} & \multicolumn{2}{|c|}{$<0,001$} \\
\hline \multicolumn{7}{|l|}{ Şirket Deneyimi } \\
\hline $1-4 \mathrm{y} 1 \mathrm{l}$ & $4,03 \pm 0,91^{b}$ & $4,33(1,89-5,00)$ & $3,62 \pm 0,79 \mathrm{~b}$ & $4,00(2,20-5,00)$ & $4,07 \pm 0,65^{b}$ & $4,38(1,88-4,88)$ \\
\hline $5-8$ y1l & $3,64 \pm 1,02^{b}$ & $4,11(1,89-4,89)$ & $3,35 \pm 0,87 \mathrm{~b}$ & $3,80(2,00-4,80)$ & $3,91 \pm 0,68^{b}$ & $4,00(2,88-4,88)$ \\
\hline $9-12$ y1l & $2,72 \pm 0,96^{a}$ & $2,39(1,67-4,89)$ & $2,81 \pm 0,78^{a}$ & $2,60(1,60-4,40)$ & $3,06 \pm 0,83^{a}$ & $2,75(1,88-4,75)$ \\
\hline 13 y1l ve üzeri & $2,79 \pm 0,83^{\mathrm{a}}$ & $2,61(1,67-4,22)$ & $2,81 \pm 0,75^{a}$ & $2,60(2,00-4,20)$ & $3,20 \pm 0,87 \mathrm{a}$ & $3,06(2,00-5,00)$ \\
\hline Test istatistiği & \multicolumn{2}{|c|}{$\mathrm{F}=13,151$} & \multicolumn{2}{|c|}{$\mathrm{F}=7,235$} & \multicolumn{2}{|c|}{$\mathrm{F}=13,413$} \\
\hline $\mathrm{p}$ & \multicolumn{2}{|c|}{$<0,001$} & \multicolumn{2}{|c|}{$<0,001$} & \multicolumn{2}{|c|}{$<0,001$} \\
\hline \multicolumn{7}{|l|}{ Çalışma Statüsü } \\
\hline Kabin Memuru & $3,80 \pm 1,01$ & $4,22(1,89-5,00)$ & $3,47 \pm 0,84$ & $4,00(2,00-5,00)$ & $3,97 \pm 0,69$ & $4,31(1,88-4,88)$ \\
\hline Kabin Amiri & $3,16 \pm 1,07$ & $2,67(1,67-4,89)$ & $3,06 \pm 0,86$ & $2,60(1,60-4,40)$ & $3,40 \pm 0,91$ & $3,13(1,88-5,00)$ \\
\hline Test istatistiği & \multirow{2}{*}{\multicolumn{2}{|c|}{$\begin{array}{c}\mathrm{t}=3,261 \\
\mathbf{0 , 0 0 1}\end{array}$}} & \multirow{2}{*}{\multicolumn{2}{|c|}{$\begin{array}{c}\mathrm{t}=2,577 \\
\mathbf{0 , 0 1 1} \\
\end{array}$}} & \multirow{2}{*}{\multicolumn{2}{|c|}{$\begin{array}{c}\mathrm{t}=3,605 \\
\mathbf{0 , 0 0 1}\end{array}$}} \\
\hline $\mathrm{p}$ & & & & & & \\
\hline
\end{tabular}

t: Bağımsız iki örnek t test istatistiği, F: Tek yönlü varyans analizi test istatistiği, a-c: Aynı harfe sahip gruplar arasında fark yoktur. 
Tablo 6'da yaşa göre duygusal tükenme puanının ortalama değerleri farklılık göstermektedir $(\mathrm{p}<0,001)$. 18-25 yaş grubunun ortalaması 4,22, 26-35 yaş grubunun ortalamas 13,33, 36 ve üzeri yaşında olanların puan ortalaması 2,79 olarak elde edilmiştir. Bu farklılık 18-25 yaş grubunun puan ortalamasının diğer grupların puan ortalamalarından yüksek olarak elde edilmesinden kaynaklanmaktadır. Yaşa göre duyarsızlaşma puanının ortalama değerleri farklılık göstermektedir $(\mathrm{p}<0,001)$. 18-25 yaş grubunun ortalaması 3,71, 26-35 yaş grubunun ortalaması 3,19, 36 ve üzeri yaşında olanların puan ortalaması 2,85 olarak elde edilmiştir. Bu farklılık 18-25 yaş grubunun puan ortalamasının diğer grupların puan ortalamalarından yüksek olarak elde edilmesinden kaynaklanmaktadır. Yaşa göre kişisel başarı düşüklüğü puanının ortalama değerleri farkl1lık göstermektedir $(\mathrm{p}<0,001)$. 18-25 yaş grubunun ortalaması 4,21, 26-35 yaş grubunun ortalaması 3,67, 36 ve üzeri yaşında olanların puan ortalaması 3,09 olarak elde edilmiştir. En yüksek ortalama değer 18-25 yaş grubunda elde edilmişken en düşük ortalama değer 36 yaş ve üzeri olanlarda elde edilmiştir.

Eğitim durumu ile tükenmişlik alt faktörleri arasında ilişkinin olmadığı görülse de ( $p>0,050)$, duygusal tükenme alt faktöründe istatistiki olarak kanıtlamayan bir ilişkiden söz edilebilir. Lise mezunu olanların puan ortalaması 3,54, önlisans mezunu olanların puan ortalaması 3,23 ve lisans ve üzeri mezun olanların puan ortalaması 3,80 olarak elde edilmiştir.

Sektör deneyimine göre duygusal tükenme puanı ortalama değerleri farkllık göstermektedir $(\mathrm{p}<0,001)$. Deneyim y1l 1-4 yıl olanların puan ortalaması 4,09, 5-8 y1 olanların puan ortalaması 3,40, 9-12 y1 olanların puan ortalaması 3,19, 13 yıl ve üzeri olanların puan ortalaması 2,73 olarak elde edilmiştir. Bu farklılık sektör deneyim yılı 1-4 yıl olanların puan ortalamasının diğer deneyim yılları puan ortalamalarından yüksek olarak elde edilmesinden kaynaklanmaktadır. Sektör deneyimine göre duyarsızlaşma puanı ortalama değerleri farklılık göstermektedir $(\mathrm{p}<0,001)$. Deneyim yılı 1-4 y1l olanların puan ortalaması 3,67, 5-8 y1l olanların puan ortalaması 3,20, 9-12 yıl olanların puan ortalaması 3,08, 13 yıl ve üzeri olanların puan ortalaması 2,79 olarak elde edilmiştir. Bu farkl1lık sektör deneyim yllı 1-4 yıl olanların puan ortalamasının diğer deneyim yılları puan ortalamalarından yüksek olarak elde edilmesinden kaynaklanmaktadır. Sektör deneyimine göre kişisel başarı düşüklüğü puanı ortalama değerleri farklılık göstermektedir $(\mathrm{p}<0,001)$. Deneyim yll 1-4 y1l olanların puan ortalaması 4,14, 5-8 yil olanların puan ortalaması 3,70, 9-12 yıl olanların puan ortalaması 3,45, 13 yıl ve üzeri olanların puan ortalaması 3,17 olarak elde edilmiştir. Bu farkll1ık sektör deneyim y1l 1-4 yıl olanların puan ortalamasının 9-12 y1l, 13 yll ve üzeri deneyim yıllarının puan ortalamalarından yüksek olarak elde edilmesinden kaynaklanmaktadır. 
Şirket deneyimine göre duygusal tükenme puanı ortalama değerleri farklllık göstermektedir $(p<0,001)$. Şirket deneyimi $1-4$ yıl olanların puan ortalaması 4,03, 5-8 y1l olanların puan ortalaması 3,64, 9-12 yl olanların puan ortalaması 2,72, 13 y1l ve üzeri olanların puan ortalaması 2,79 olarak elde edilmiştir. Bu farklılık, deneyim y1lı 1-4 yıl ve 5-8 yıl olanların puan ortalamalarının diğer deneyim yılları puan ortalamalarından yüksek olarak elde edilmesinden kaynaklanmaktadır. Şirket deneyimine göre duyarsızlaşma puanı ortalama değerleri farklılık göstermektedir $(\mathrm{p}<0,001)$. Deneyim yılı 1-4 y1l olanların puan ortalaması 3,62, 5-8 y1l olanların puan ortalaması 3,35, 9-12 yıl olanların puan ortalaması 2,81, 13 y1l ve üzeri olanların puan ortalaması 2,81 olarak elde edilmiştir. Bu farklılık şirket deneyim yllı 1-4 y1l ve 5-8 yıl olanların puan ortalamalarının diğer deneyim yılları puan ortalamalarından yüksek olarak elde edilmesinden kaynaklanmaktadır. Şirket deneyimine göre kişisel başarı düşüklüğü puanı ortalama değerleri farkl1lık göstermektedir ( $\mathrm{p}<0,001)$. Deneyim y1lı 1-4 y1l olanların puan ortalamas1 4,07, 5-8 y1l olanların puan ortalamas1 3,91, 9-12 y1l olanların puan ortalaması 3,06, 13 yıl ve üzeri olanların puan ortalaması 3,20 olarak elde edilmiştir. Bu farklılık, deneyim y1lı 1-4 yıl ve 5-8 yıl olanların puan ortalamalarının diğer deneyim yılları puan ortalamalarından yüksek olarak elde edilmesinden kaynaklanmaktadır.

Çalışma statüsüne göre duygusal tükenme puanı ortalama değerleri farkl1lık göstermektedir ( $p=0,001)$. Kabin memuru olanların puan ortalaması 3,80 iken, kabin amirinin puan ortalaması 3,16 olarak elde edilmiştir. Çalışma statüsüne göre duyarsızlaşma puanı ortalama değerleri farklılık göstermektedir $(\mathrm{p}=0,011)$. Kabin memuru olanların puan ortalaması 3,47 iken, kabin amirinin puan ortalaması 3,06 olarak elde edilmiştir. Çalışma statüsüne göre kişisel başarı düşüklüğü puanı ortalama değerleri farklllık göstermektedir $(\mathrm{p}=0,001)$. Kabin memuru olanların puan ortalaması 3,97 iken, kabin amirinin puan ortalamas1 3,40 olarak elde edilmiştir.

Diğer demografik özelliklere göre duygusal tükenme, duyarsızlaşma ve kişisel başarı düşüklüğü puanlarının ortalama değerleri arasında istatistiksel olarak anlamlı bir fark bulunmamıştır $(\mathrm{p}>0,050)$.

\section{SONUÇ VE ÖNERİLER}

Hizmet sektöründe yer alan işletmeler, artan rekabet koşulları nedeniyle müşterilerine daha iyi ve kaliteli hizmet sunmanın ve rakiplerinin önüne geçmenin çabası içindedirler. Tıpkı diğer hizmet sektörlerinde olduğu gibi havacilık sektöründe de insan emeği söz konusudur ve bu emek, diğer üretim faktörleriyle birleşerek işletmenin amaçlarını gerçekleştirmesinde 
katkıda bulunmaktadır. Öte yandan üretim faktörleri içerisinde en önemlisi ve en zor kontrol edileni emek faktörüdür. Bu nedenle Maslach’n yaygın olarak kullanılan tükenmişlik ölçeği, emek faktörünü de dikkate alan ve sorunları irdelemeye yarayan bir araç olarak bu tür çalışmalarda genel kabul görmüştür.

$\mathrm{Bu}$ çalışmanın sonuçları yorumlanırken birtakım kısıtlamalar göz önünde bulundurulmalıdır. Araştırmanın kısıtları şu şekildedir: Bu çalışma, tüm havayolu şirketlerinin çalışanlarına ulaşmakta zorluk yaşandığı için sadece bir özel havayolu şirketinin çalışanlarına uygulanmıştır. Bazı çalışanlar, bu araştırmanın çalıştıkları şirket tarafindan yapıldığını düşünerek eleştirel cevaplarının şirkette sorun yaratacağı ihtimaline karşı araştırmaya katılmak istememişlerdir. Çalışanların bir kısmı yatı görevinde olduğu için kendilerine ulaşılamamıştır. Araştırma bulguları, kabin ekibi çalışanlarının araştırmaya katıldıktan sonra yaşayabilecekleri olumlu ya da olumsuz deneyimler sonucu farklll1k gösterebilir.

Yapılan analizler sonucunda, çalışanların cinsiyetleri ile tükenmişlik alt boyutlanı arasında anlamlı bir fark olmadığı tespit edilmiştir ( $p>0,050)$. Tuna (2019) ve Şahin’in (2014) araştırmalarında da cinsiyete göre tükenmişliğin farklılaşması anlamlı bulunmamıştır.

Katılımcıların yaş değişkenine göre duygusal tükenme, duyarsızlaşma ve düşük kişisel başarı alt boyutlarında istatistiksel açıdan anlamlı farklılıklar olduğu tespit edilmiştir. 18-25 yaş aralı̆̆ındaki katıllımcıların 26-35 yaş aralığındaki ve 36 yaş ve üzeri olan katılımcılara göre duygusal tükenme, duyarsızlaşma ve düşük kişisel başarı düzeylerinin daha yüksek olduğu görülmektedir. Yaş ilerledikçe çalsşanların tükenmişlik konusunda daha dayanıklı olmaları zamanla kazanilan olgunluk ve sorumluluk duygusundan kaynaklanabilir. Konak'ın (2020) yaptığ1 araştırmada da yaş ile tükenmişlik alt boyutları arasında anlamlı farkll1ıklar olduğu; Öztürk'ün (2019) çalışmasında ise yaş ile düşük kişisel başarı arasında pozitif ilişkiler olduğu tespit edilmiştir.

Evli olan katılımcıların düzensiz çalışma saatlerinden, hafta sonu yapılan uçuşlardan ve yatı görevlerinden daha fazla olumsuz yönde etkilenmeleri beklenirken evli olup olmamanın mesleki açıdan bir fark yaratmadığı anlaşılmaktadır. Aynı durum çocuk durumu için de geçerlidir. Ayrıca boşanmış olan katılımcıların evli ve bekarlara göre duygusal tükenme, duyarsızlaşma ve kişisel başarı düşüklüğü düzeylerinin daha yüksek olabileceği düşünülmüş ancak anlamlı farklılıklar ortaya çıkmamıştır. Konak (2020) ve Şahin (2014) de bu çalışmayı destekleyici şekilde medeni duruma göre tükenmişlik alt boyutlarının anlamlı düzeyde farklılaşmadığı sonucunu elde etmişlerdir.

Kabin ekibi çalışanlarının en az lise mezunu olması yeterlidir. Buna rağmen eğitim düzeylerine bakıldığında lisans mezunu olan katılımcıların oranı \%37,9'dur. Bu durum, lisans 
mezunlarının kendi branşlarında çalışma imkanı bulamadıklarını ya da çalışmak istemediklerini akla getirmiş ve mecbur kaldıkları için bu mesleği yaptıkları düşünülerek tükenmişlik alt boyutlarının daha yüksek çıkacağı öngörülmüştür. Ancak tükenmişlik alt boyutlarında herhangi bir farklılık olmadığı tespit edilmiştir ( $>$ >0,050). Kadıŏlu'nun (2019) çalışmasında da katılımcıların eğitim durumlarına göre tükenmişlik alt boyutlarında istatistiksel açıdan anlamlı farklılıklar olmadığı görülmektedir.

Çalışanların sektör deneyimine göre duygusal tükenme, duyarsızlaşma ve düşük kişisel başarı alt boyutlarında istatistiksel açıdan anlamlı farklılıklar olduğu görülmektedir. Sektör deneyimi 1-4 yıl olanların diğer deneyim yıllarına göre duygusal tükenme, duyarsızlaşma ve düşük kişisel başarı düzeylerinin yüksek olduğu tespit edilmiştir. Zaman geçtikçe edinilen tecrübe sayesinde çalşanların daha az duygusal tükenmeye ve duyarsızlaşmaya maruz kaldıkları ve kendilerini daha başarılı hissettikleri düşünülmektedir. Sektör deneyimi az olan çalşanların sektörden beklentileri ile edindikleri tecrübe aynı olmayabilir.

Katılımcıların şirket deneyimine göre duygusal tükenme, duyarsızlaşma ve düşük kişisel başarı alt boyutlarında istatistiksel açıdan anlamlı farklılıklar olduğu, bunun da şirket deneyimi 1-4 yıl ve 5-8 yıl olan çalışanların puan ortalamalarının diğer deneyim yılları puan ortalamalarından daha yüksek olmasından kaynaklandığı görülmektedir. Şirket deneyimi 1-4 yıl olan katılımcıların puan ortalamalarının daha yüksek olmasının nedenleri arasında meslek ve/veya şirket kriterlerinin çalışanların beklenti düzeylerinin altında kalması olabilir. Normal şartlarda dışarıdan bakıldığında bu mesleğin gezmeye, yeni yerler görmeye imkan tanıdığı ve çalışanlarına yüksek hayat standartları sunduğu düşünülür. Oysaki her mesleğin zorluğu olduğu gibi bu mesleğin de birtakım zorlukları vardır. Bu zorlukların başında çalışma saatlerinin düzensiz olması, insanlarla sürekli iletişim halinde olmak, sorunlu yolcularla ilgilenmek, yerde ya da havada acil durum yaşamak gelir. Bu gibi zorlukların üstesinden gelmek, tecrübesiz çalışanlar için daha zor olabilir. Tuna'nın (2019) çalışmasında da 1-5 yıl arası çalışan kabin ekiplerinin 16 yll ve üzeri olan çalışanlara göre tükenmişlik alt boyutları yüksek çıkmıştır.

Çalışma statüsüne bakıldığında, kabin memuru olanların kabin amiri statüsündeki çalışanlara göre duygusal tükenme, duyarsızlaşma ve düşük kişisel başarı düzeylerinin daha yüksek olduğu görülmektedir. Kabin memurlarının tükenmişlik alt boyutlarının daha yüksek olmasının nedenleri arasında yolcularla daha çok muhatap olmaları, çalışanlar arasındaki altüst ilişkisi ve/veya şirketin maaş politikası olabilir. Kabin memurları, uçuşun her safhasında yolcularla daha çok iletişim halindedirler. Yolcu yerleşiminde, ikram servisinde ve diğer 
süreçlerde yolcuyla birebir muhatap oldukları için yaşanan aksaklıklardan ve yolcuların olumsuz tavırlarından daha çok etkilenebilirler. Diğer yandan kabin amirinin ekip üyelerine yaklaşım tarzı ve ekiple kurduğu iletişim de son derece önemlidir. Yapılan işin zorluğu yanında, kabin amirinin baskısı ve agresif tutumu çalışanlar üzerinde olumsuz etki yaratacaktır. Diğer bir olasıllk da çalışanlar arasındaki ücret dengesizliğidir. Statüye göre maaşlar arasında uçurum olması da kabin memurlarını olumsuz yönde etkileyecektir. Tuna’nın (2019) çalışmasında da kabin memurlarının duyarsızlaşma düzeylerinin daha yüksek olduğu görülmüştür.

Sonuç olarak kabin ekibi çalışanlarının yıllar geçtikçe ve deneyim kazandıkça işlerine daha profesyonel yaklaştıkları görülmektedir. Bu çıkarıma dayanarak duygusal tükenme, duyarsızlaşma ve düşük kişisel başarı sorunu yaşayan çalışanların kendilerinden daha kıdemli ve yaşça büyük olan meslektaşlarını örnek almaları tavsiye edilmektedir. Kıdemli ve yaşça büyük olan kabin ekibi çalışanlarının da görev halindeyken ekip arkadaşlarına yapıcı ve pozitif davranmaları, iş ile ilgili her türlü desteği vermeleri, onları yönlendirmeleri, mesleki bilgi ve tecrübelerini onlarla paylaşmaları önerilmektedir. .

Öte yandan havayolu şirketleri, işine hakim ve acil durumlarda ne yapması gerektiğini iyi bilen tecrübeli çalışanların değerini bilmelidirler. Tecrübeli çalışanların mesleki bilgi ve deneyimlerini genç yaştakilere aktarmaları konusunda da şirketlerin yönlendirici olmalarında fayda vardir.

Tükenmiş ya da tükenme eğiliminde olan çalışanlar, görev esnasında işlerini tam olarak yerine getirmeyebilirler, iş ortamında negatif bir tutum sergileyebilirler ya da şirketlerine iletemedikleri memnuniyetsizliklerini ekip arkadaşlarıyla paylaşırlar. Bu da diğer çalışanların motivasyonunu olumsuz yönde etkileyebilir. Bu nedenle şirketlerin çalışanlarıyla iyi iletişim kurmaları, onların talep ve önerilerini dikkate almaları, varsa sorunlarıyla ilgilenmeleri ve ekip kaynak yönetimi üzerinde daha fazla durmaları tavsiye edilmektedir.

Yaptığı işe, çalıştığ1 şirkete ya da kendi özel hayatına yönelik olumsuz düşünceler beslemeye başlayan çalışanlar, bu düşüncenin kaynağını zamanında tespit etmeli, geç kalmadan mücadele tarzı belirlemeli ya da bir uzmandan yardım almalıdırlar. Tükenmişliği tetikleyebilecek olumsuzluklardan biri de problemli yolculara hizmet vermektir. Sebebi ne olursa olsun problem çıkaran yolcular, kabin ekibinin işini oldukça zorlaştırmaktadır. Zor şartlarda bile soğukkanlıllğını korumak ve şirket prosedürlerini yerine getirmek durumunda olan çalışanların hizmet sektöründe bu tür sıkıntıların yaşanabileceğini düşünerek olayları içlerinde büyütmemeleri kendileri açısından faydalı olacaktır. Yaşanan her olay aslında 
çalışana tecrübe katar. Ayrıca şirket, çalışanın haklılığı durumunda onu yalnız bırakmamalı ve desteğini hissettirmelidir.

Bir kabin ekibi üyesi, uçuşa katılmadan önce psikolojik sorun ya da görev yapmasını güçleştirecek bir sağlık problemi yaşayabilir. İşten çıkarılma korkusuyla sağlık raporu almayıp uçuşa katılan bu kabin ekibi üyesi, uçuşta diğer çalışanların iş yükünü arttırır, kendini işe veremez ve en önemlisi uçuş emniyetini tehlikeye atabilir. Uçuşa katılamayacak durumda olan çalışanların işten çıkarılma korkusu yaşamadan bunu dile getirebilmeleri ve rapor almaları için havayolu şirketlerinin bu konuda daha anlayışlı davranmaları gerekir.

Havayolu şirketleri, özellikle gelir dağılımı ve terfi konusunda çalışanlarına şeffaf ve adaletli olmak durumundadırlar. Kabin amiri ile kabin memurunun masşları ve primleri arasında uçurum olmamalı, her seviyedeki çalışana hak ettiği maaş ve prim verilmelidir. $\mathrm{Bu}$ aynı zamanda çalışanın motivasyonu ve performansı açısından önemlidir. Terfi konusunda da çalışanlar arasında eşitlik gözetilmelidir. Örneğin; aynı tecrübeye sahip iki kabin memurundan biri kabin amirliğine terfi edip diğeri edemediğinde, amir olamayan çalışan küstürülmemeli, eksik yönleri dile getirilmeli ve eksikliklerini tamamlaması yönünde desteklenmelidir.

Düzensiz, yoğun ve uzun mesafeli uçuşlar, kabin ekibinin çalışma koşullarını zorlaştırmaktadır. Bu nedenle çalışanların uçuş programının iyi ayarlanması gerekir. Örneğin; bir kabin ekibi üyesine sürekli gece uçuşu verilip diğerine devamlı öğlen uçuşu verilmesi adaletli olmayacaktır. Öğlen vakti uçuşlara giden personel, uykusunu almış ve dinç bir şekilde uçuşa katılırken, gece uçuşlarına giden personel yeterince istirahat alamadan görevini icra edecektir. Kabin ekiplerinin her gittikleri yerde gezme imkanları yoktur. Çoğu zaman yapılan uçuşlar git-gel şeklindedir. Ancak bazı iç hat ya da dış hat seferlerinde yatı görevi yapılmaktadır. Kabin ekibi çalışanları, yatı harcırahı almak ve yeni yerler gezip görmek amacıyla çoğu zaman yatı görevi yapmaya isteklidirler. Bu nedenle ekip planlama biriminin bu konuda da mümkün olduğunca hassas ve adaletli davranması gerekir. Ekip planlamacıların tercihen kabin memurluğu ya da kabin amirliği tecrübesinin olması, kabin ekibi çalşsanlarının yararına olacaktır. Çünkü yapılan işin zorluğunu bilen ve tecrübe eden planlamacının daha titiz ve duyarlı davranma ihtimali yüksektir.

Ayrıca çalışanların performanslarıyla ilgili ödül programları uygulanabilir ya da varsa geliştirilebilir. Böylece kabin ekibi üyesi, daha özverili çalışacak ve hizmet verdiği insanların sorunlarını daha etkili bir şekilde ele alacaktır. Örneğin; müşterilerin olumlu geri dönüşleri, ödül kazanma kriteri olabilir.

Kabin ekibinin yaptı̆̆ iş bir ekip işidir, sosyallik ve iyi iletişim gerektirir. Belirli aralıklarla tanışma yemeklerinin, sosyal aktivitelerin ve sosyal sorumluluk projelerinin 
düzenlenmesi ya da daha sık yapılması, çalışanlarda ekip ruhunu canlandırır, aidiyetlik duygusunu arttırır ve iş ortamı haricinde kaynaşmayı sağlar.

\section{KAYNAKÇA}

ABACI, Z. K. (2004), Sosyal Hiæmetler ve Cocuk Esirgeme Kurumuna Bağh Saray ve Ayaş Rehabilitasyon Merkeeqinde Bakema İbtiyac Duyan Bireylerin Bakemmdan Sorumlu Personelin Iss Doyumu, Tükenmisslik, Stres ve Depresyon Dü̈reyleri Açssndan Karşılassturlmass. (Yüksek Lisans Tezi). Ankara Üniversitesi/Sosyal Bilimler Enstitüsü Psikoloji Anabilim Dalı, Ankara.

ALTUNIŞIK, R., COŞKUN, R., BAYRAKTAROĞLU, S. ve YILDIRIM, E. (2010), Sosyal Bilimlerde Araştrma Yöntemleri (6.Baskı). Adapazarı: Sakarya.

ARDIÇ, K. ve POLATCI, S. (2008), Tükenmişlik Sendromu Akademisyenler Üzerinde Bir Uygulama (GOÜ Örneği), Gari Üniversitesi İktisadi ve İdari Bilimler Fakültesi Dergisi, 10(2), 69-96.

ARPACI, S. ve ÖZEK, Y. (2019), Finans Sektöründe Ekonomik Kayg1 ve Tükenmişlik Düzeylerinin Örgütsel Bağlllığa Etkisi, Kastamonu Üniversitesi İktisadi ve İdari Bilimler Fakültesi Dergisi, 2, 99-125.

BARUTÇU, E. ve SERINKAN, C. (2008), Günümüzün Önemli Sorunlarından Biri Olarak Tükenmişlik Sendromu ve Denizli’de Yapılan Bir Araştırma, Ege Akademik Bakış Dergisi, 2, 541-561.

BILGIN, N. (2003), Sosyal Psikoloji Sö̌llïgüi, İstanbul: Bağlam. Guilford.

BROWN, T. A. (2006), Confirmatory Factor Analysis for Applied Research, New York: The

BYME, B. M. (2016), Structural Equation Modeling with AMOS (3rd Edn.), New York.

CHERNISS, C. (1980), Professional Burnout In Human Service Organizations. Praeger, New York.

ÇAĞLIYAN, Y. (2007), Tükenmişlik Sendromu ve Iss Doyumuna Etkisi: Devlet ve Vakerf Üniversitelerine Yönelik, Alan Araststrmas,, (Yüksek Lisans Tezi). Kocaeli Üniversitesi/Sosyal Bilimler Enstitüsü Çalı̧sma Ekonomisi Anabilim Dalı, Kocaeli.

DEMiR, A. (1995), Hemșirelerin Tükenmişlik Düzeyleri ve Tükenmisliği Etkileyen Bažl Faktörlerin İncelenmesi. (Yayımlanmamış Yüksek Lisans Tezi). Cumhuriyet Üniversitesi/Sağlık Bilimleri Enstitüsü, Sivas.

ERGIN, C. (1992), Doktor ve Hemșirelerde Tükenmislike ve Maslach Tükenmişlik Ölçeginin Uyarlanması, VII. Ulusal Psikoloji Kongresi, Hacettepe Üniversitesi, Ankara.

FREUDENBERGER, H. J. (1974), Staff Burnout, Journal of Social Issues, 30, 159-165.

GARVER, M.S., and MENTZER, J.T. (1999), Logistics Research Methods: Employing Structural Equation Modeling to Test for Construct Validity, Journal of Business Logistics, 20(1), 33-57.

GERBING, D.W., and ANDERSON, J.C. (1992), Monte Carlo Evaluations of Goodness of Fit Indices for Structural Equation Models, Sociological Methods and Research, 21(2), 132-160.

GEZER, E. Yenel, F. ve ŞAHIN, H. (2009), Öğretim Elemanlarının Tükenmişlik Düzeyleri ile Sosyodemografik Değişkenleri Arasındaki İlişki, Uluslararası Sosyal Araștrmalar Dergisi - The Journal of International Social Research Volume, 2(6), 243-250. 

Seçkin.

GÜRBÜZ, S. ve ŞAHİN, F. (2018), Sosyal Bilimlerde Araştırma Yöntemleri (5.Baskı). Ankara:

GÜRBÜZ, S. (2019), AMOS ile Yapısal Eşitlik Modellemesi. Ankara: Seçkin.

HELVACI, I. ve TURHAN, M. (2013), Tükenmişlik Düzeylerinin İncelenmesi: Silifke’de Görev Yapan Sağlık Çalışanları Üzerinde Bir Araştırma, İsletme ve İktisat Calışmalar Dergisi, 4, 58-68.

HU, L-T. and BENTLER, P. M. (1998), Fit Indices in Covariance Structure Modeling: Sensitivity to Underparameterized Model Misspecification, Psychological Methods, 3, 424-453.

IACOBUCCI, D. (2010), Structural Equations Modeling: Fit Indices, Sample Size and Advanced Topics, Journal of Consumer Psychology, 20, 90-98.

IŞIKHAN, V. (2004), Calışma Hayatında Stres ve Başa Cıkma Yollar. Ankara: Sandal.

IZGAR, H. (2003), Okul Yöneticilerinde Tükenmişlik (2. Baskı). Ankara: Nobel.

İLHAN, M. ve ÇETIN, B. (2014), LISREL ve AMOS Programları Kullanılarak Gerçekleştirilen Yapısal Eşitlik Modeli (YEM) Analizlerine İlişkin Sonuçların Karşılaştırılması, Eğitimde ve Psikolojide Ölçme ve Değerlendirme Dergisi, 2, 26-42.

KADIOĞLU, R. (2019), Havacılık Organizasyonlarnda Calışan Lojistik Profesyonellerinde $\dot{I}_{s}$ Doyumu ve Tükenmişlik: Kokpit ve Kabin Personelleri Üzerine Bir Uygulama. (Yüksek Lisans Tezi). Akdeniz Üniversitesi/Sosyal Bilimler Enstitüsü, Antalya.

KARACAOĞLU, K. ve ÇETİN, İ. (2015), İş Yükü ve Rol Belirsizliğinin Çalışanların Tükenmişlik Düzeyleri Üzerine Etkisi: Afad Örneği, Nevşehir Hacı Bektaş Veli Üniversitesi SBE Dergisi, 5, 46-69. The Guilford.

KLINE, R. B. (2016). Principles and Practice of Structural Equation Modeling (4th Edn.). London:

KONAK, İ. (2020), Uçus Ekiplerinde İs Doyumu, Örgütsel Stres, Psikosomatik Belirtiler ile Tükenmişlik Düreyi Arasındaki İlişki: Bir Havayolu Şirketi Örneği. (Yüksek Lisans Tezi). İstanbul Gelişim Üniversitesi/Lisansüstü Eğitim Enstitüsü, İstanbul.

MASLACH, C. and JACKSON, S. E. (1986), Maslach burnout inventory manual, Palo Alto, Ca: Consulting Psychologist Press.

ÖRMEN, U. (1993), Tükenmişlike Duygusu ve Yöneticiler Üzerinde Bir Uygulama. (Yayımlanmamış Yüksek Lisans Tezi). Marmara Üniversitesi/Sosyal Bilimler Enstitüsü, İstanbul.

ÖZTÜRK, E. (2019), Havacılk Sektöründe Tükenmişlik Sendromu Nedenleri ve Etkileri. (Yüksek Lisans Tezi). Kocaeli Üniversitesi/Sosyal Bilimler Enstitüsü, Kocaeli.

PEPE, Ş. (2008), Beden Ë̆itimi ve Spor Öğretmenlerinin Mesleki Tükenmişlik Düzeylerinin İncelenmesi. (Yayımlanmamış Yüksek Lisans Tezi). Selçuk Üniversitesi/Sağlık Bilimleri Enstitüsü, Konya.

POLATCI, S. (2007), Tükenmişlik Sendromu ve Tükenmişlik Sendromuna Etki Eden Faktörler: Gaziosmanpaşa Üniversitesi Akademik Personeli Üzerinde Bir Analiæ. (Yüksek Lisans Tezi). Gaziosmanpaşa Üniversitesi/Sosyal Bilimler Enstitüsü İşletme Ana Bilim Dalı, Tokat.

SÜRGEVİ, O. (2006), Calışma Hayatında Tükenmişlik Sendromu, Tükenmislikle Mücadele Teknikleri (1.Baskı). Ankara: Nobel. 
ŞAHIN, M. S. (2014), Iss Stresinin Tükenmislik Üzerine Etkisi ve Devlet Hava Meydanlar $\dot{I}_{s}$ letmesinde Calışan Hava Trafik Kontrolörleri Üzerine Bir Araştırma. (Yayımlanmamış Yüksek Lisans Tezi). İstanbul Aydın Üniversitesi/Sosyal Bilimler Enstitüsü, İstanbul.

TORUN, A. (1995), Tükenmişlik, Aile Yapısı ve Sosyal Destek Ilişkileri Üzerine Bir İnceleme. (Doktora Tezi). Marmara Üniversitesi/Sosyal Bilimler Enstitüsü İngilizce İşletme Bölümü Örgütsel Davranış Anabilim Dalı, İstanbul.

TUNA, G. (2019), Kabin Memurlarmm Tükenmişlik Düzeylerinin Örgütsel Bağhllk ve Calıșma Performanslarna Etkisi Üzerine Bir Araștırma. (Yüksek Lisans Tezi). Beykent Üniversitesi/Sosyal Bilimler Enstitüsü İşletme Ana Bilim Dalı İşletme Yönetimi Bilim Dalı, İstanbul.

YILMAZ, H. ve KARAHAN, A. (2009), Bireylerin Kişisel Özellikleri Yönünden İş Doyum Düzeylerine Göre Tükenmişlikleri: Afyonkarahisar İlinde Bir Araştırma, Süleyman Demirel Üniversitesi İktisadi ve İdari Bilimler Fakültesi Dergisi, 3, 197-214.

SHGM, (2021), Faaliyet Raporlarmız, 03 Mart 2021 tarihinde http://web.shgm.gov.tr/documents/sivilhavacilik/files/pdf/kurumsal/faaliyet/2020.pdf adresinden alınd. 